\title{
Genetic diversity of Brazilian boll weevil populations based on morphometric characteristics and ISSR molecular markers
}

\author{
S.K. dos Santos ${ }^{1}$, L.H.A. Araújo ${ }^{2}$, F.A. de Albuquerque ${ }^{2}$, \\ C.A.D. da Silva ${ }^{2}$ and L.M. de Lima ${ }^{3}$ \\ ${ }^{1}$ Universidade Estadual da Paraíba, Programa de Pós-Graduação em \\ Ciências Agrárias, Universitário, Campina Grande, PB, Brasil \\ ${ }^{2}$ Embrapa Algodão, Laboratório de Entomologia, Centenário, Campina \\ Grande, PB, Brasil \\ ${ }^{3}$ Embrapa Algodão, Laboratório de Biotecnologia, Centenário, Campina \\ Grande, PB, Brasil
}

Corresponding author: L.M. de Lima

E-mail: liziane.lima@embrapa.br

Genet. Mol. Res. 20 (2): gmr18771

Received March 14, 2021

Accepted April 16, 2021

Published April 30, 2021

DOI http://dx.doi.org/10.4238/gmr18771

\begin{abstract}
The boll weevil, Anthonomus grandis (Curculionidae) is the main pest of cotton culture. To establish more efficient forms of control, it is important to understand its genetic structure and the diversity of its populations. We examined the genetic diversity of various populations of boll weevils, collected from several Brazilian locations, through morphometric and molecular analyses. Flower buds were collected from cotton plantations in three municipalities in the Caatinga region and seven municipalities in the Brazilian Cerrado region. Fifty specimens from each population (municipality) were randomly selected for morphometric characterization and 15 specimens, among the 50 insects characterized morphometrically, were randomly selected for molecular characterization. In the analysis of the principal components, based on 13 morphometric characteristics, the variables that had the most impact on the first two eigenvectors of males and females were total body length and maximum prothorax width. Based on the band count obtained from the ISSR markers, and subsequent construction of the binary matrix, the averages of the number of loci, percentage of polymorphic bands and expected heterozygosity were $71,53 \%$, and
\end{abstract}


0.126 , respectively. The genetic variation within and between populations was 42.69 and $57.30 \%$, respectively. Using the unweighted pair group method, formation of two population groups was observed after adopting the $95 \%$ cut-off point; the clusters formed using molecular data were different from the clusters of males and females formed using morphometric data. The low genetic diversity and the weak geographical structure of the boll weevil in Brazil is apparently due to its being an exotic pest that has been recently introduced, composed of a small portion of the population of origin. The low diversity also indicates that geographically closer populations are not necessarily genetically similar.

Key words: Anthonomus grandis; Body length; Prothorax width; Heterozygosity; Morphometric marker

\section{INTRODUCTION}

The boll weevil, Anthonomus grandis (Coleoptera: Curculionidae), is the principal cotton pest in the Americas (Silva and Ramalho, 2013). Adults are small beetles with a wingspan of about $7 \mathrm{~mm}$, characterized by grayish or brown coloration, with a chewing mouthpiece in the shape of a face (Almeida et al., 2008). Flower buds are the preferred structures for feeding and oviposition of the boll weevil, although at the end of the crop cycle, females deposit their eggs in both flower buds and young cotton bolls (Ribeiro et al., 2010; Silva and Ramalho, 2013). This feeding and oviposition behavior reduces productivity and increases cotton production costs (Smith-Pardo, 2015).

The use of insecticides is the main control method for weevil management. It is estimated that between 18 and 23 insecticide applications are used per crop for their control; even so, losses can reach 200 dollars per hectare, which is equivalent to almost $10 \%$ of the total production cost (Miranda and Rodrigues, 2018). Synthetic chemical insecticides are important agricultural inputs used to control insect pests. However, if applied on a recurring basis and without technical criteria, they can cause undesirable effects on the environment, such as contamination of the agro-ecosystem, reduction and/or elimination of beneficial insects and selection of insect pest populations resistant to these products (Parra, 2014).

To mitigate these undesirable effects, knowledge of the genetic structure and gene flow among insect pest populations has been recognized as information of great importance for integrated pest management (Martinelli and Omoto, 2006). Understanding the genetic variation within and between populations of $A$. grandis, as well as the geographical distribution of this variation, may help in choosing more efficient control tactics for the management of this pest.

The population genetic diversity of insect pests can be understood through morphological characteristics, including classic morphometry (Jimenez et al., 2018) and/or by molecular markers, such as ISSRs (Kalia et al., 2011). Morphometric studies use biometric techniques that analyze physical characteristics, by measuring the distance between morphological structures, such as the width and length of body parts of these organisms (Fornel and Cordeiro-Estrela, 2012). Morphometric methods are powerful tools, when used in conjunction with biological and molecular knowledge to answer questions related to character covariation within and between populations, and still have applications in evolutionary biology (Reis, 1988; Ober and Connolly, 2015).

Studies to characterize the genetic diversity of $A$. grandis populations with molecular markers have been conducted using isoenzymes (Bancroft and Jones, 1977; Terranova et al., 
1991) and random amplified polymorphic DNA (RAPD) markers (Martins et al., 2007). However, there is no information on the use of ISSR markers for this purpose. ISSR markers produce fragments with high reproducibility, when compared to other markers based on nonspecific PCR such as RAPD and have good genome coverage and a high degree of genetic variation, which makes it possible to estimate diversity within species (Ng and Tan, 2015). In addition, they do not present the problems that the null microsatellite alleles bring to genetic analyses and that can lead to false interpretations of the results (Souza et al., 2008). We examined the genetic diversity of populations of the boll weevil in five Brazilian states, using morphometric methods and ISSR molecular markers.

\section{MATERIAL AND METHODS}

\section{Insects}

The weevil populations came from flower buds collected from cotton crops located in 10 municipalities, distributed in five Brazilian states (Figure 1), between the months of March and August 2018 and 2019. The municipalities with cotton production chosen to collect flower buds were: Barbalha, Campina Grande and Quixeramobim - located in the Caatinga region; Goiânia, Jataí, Chapadão do Ceú, Chapadão do Sul, Ipiranga do Norte, Rondonópolis and Primavera do Leste - located in the Cerrado region, where the largest cotton production in Brazil is concentrated (IBGE, 2019).

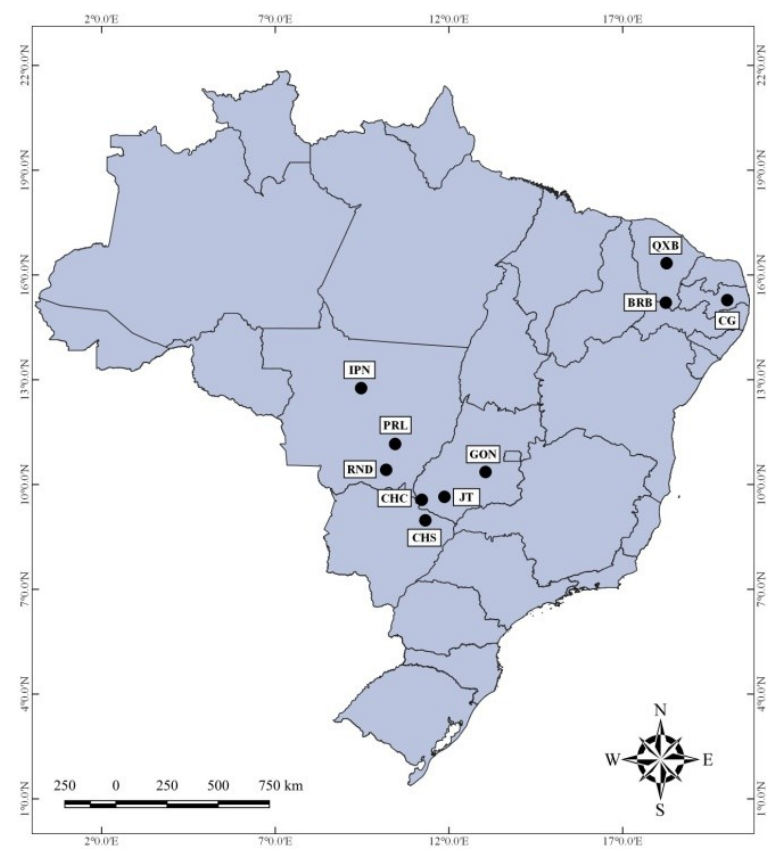

Figure 1. Map of Brazil indicating the states/ cities of Anthonomus grandis collection: Ceará - (BRB) Barbalha, (QXB) Quixeramobim; Paraíba - (CG) Campina Grande; Goiás - (GON) Goiânia, (JT) Jataí, (CHC) Chapadão do Céu; Mato Grosso do Sul - (CHS) Chapadão do Sul; Mato Grosso - (IPN) Ipiranga do Norte, (PRL) Primavera do Leste, (RND) Rondonópolis. 
Approximately 100 cotton buds measuring 5-6 $\mathrm{mm}$ in diameter from each municipality were kept in transparent plastic containers with a lid, measuring $22 \times 21 \times 10$ $\mathrm{cm}$ in width, length, and height, respectively, until the emergence of the boll weevil adults. After emergence, adult weevils were collected and stored in $70 \%$ alcohol. The specimens were identified by a dichotomous key for the Mexican and Central American genera of Anthonomini (Curculionidae, Curculioninae) (Hernández et al., 2009), mainly observing the presence of a pair of spines located in the femur of the foreleg (Kim et al., 2009).

\section{Morphometric characterization}

Fifty specimens of $A$. grandis from each location were randomly selected, fixed on a styrofoam plate with the aid of entomological pins and kept in an oven at $50^{\circ} \mathrm{C}$, for 24 hours. After drying, the insects were placed on a stereoscopic microscope and photographed from above, always at the same distance, by an Opton digital camera with an image resolution of 13 megapixels, attached to the microscope. The images were transferred to a computer containing the Image $\mathbf{J}$ Software for further measurements. All insects were sexed based on the characteristics of the rostrum (Sappington and Spurgeon, 2000; Belot, 2015). Morphometric measurements of the prothorax length (PL), prothorax base width (PBW), prothorax maximum width (PMW), elytra length (EL), base width of both elytra (BWBE), median width of both elytra (MWBE), posterior width of both elytra (PWBE), anterior width of both elytra (AWBE), rostrum length (RL), rostrum apex width (RAW), rostrum base width (RBW), head length (HL), and total body length (TBL) (Jimenez et al., 2018) of male and female insects were performed using the Image J. Software.

\section{Genomic DNA extraction and PCR-ISSR}

For the molecular characterization, genomic DNA from 15 weevils from each population was used, chosen randomly from the 50 that had been analyzed morphometrically. The DNA extraction occurred using the CTAB method (Doyle and Doyle, 1987), adapted by Ferreira and Gattapaglia (1998).

A total of 44 ISSR primers, produced by the University of British Columbia, Vancouver, Canada, were initially used, from which 15 primers (Table 1) were selected for producing fragments of different sizes.

Table 1. Sequences of 15 ISSR oligonucleotides developed by the Biotechnology Laboratory at the University of British Columbia.

\begin{tabular}{llll}
\hline Oligo & Sequence $\left(5^{\prime} \rightarrow 3^{\prime}\right)$ & Oligo & Sequence $\left(5^{\prime} \rightarrow 3^{\prime}\right)$ \\
\hline 808 & AGAGAGAGAGAGAGA GC & 834 & AGAGAGAGAGAGAGAGYT \\
812 & GAGAGAGAGAGAGAGAA & 846 & CACACACACACACACART \\
816 & CACACACACACACACAT & 855 & ACACACACACACACACYT \\
817 & CACACACACACACACAA & 868 & GAAGAAGAAGAAGAAGAA \\
818 & CACACACACACACACAG & 878 & GGATGGATGGATGGAT \\
825 & ACACACACACACACACT & 884 & HBHAGAGAGAGAGAGAG \\
826 & ACACACACACACACACC & 888 & BDBCACACACACACACA \\
827 & ACACACACACACACACG & & \\
\hline
\end{tabular}


The selection of the 15 primers was also based on the highest frequency of CA; according to Jarne and Lagoda (1996) the genome of animals is rich in these dinucleotides. The PCRs were conducted using $30 \mathrm{ng}$ of genomic DNA, reaction buffer (1X), $2 \mathrm{mM}$ $\mathrm{MgCl}_{2}, 1 \mathrm{U}$ of Taq DNA polymerase (Ludwig Biotec), $0.32 \mu \mathrm{Mol}$ of dNTPs, $0.8 \mu \mathrm{Mol}$ of oligonucleotide and completing the final volume to $25 \mu \mathrm{L}$ with autoclaved ultrapure water. The reactions were carried out in an Amplitherm Thermal Cycler thermocycler, with the following program: initial denaturation at $95^{\circ} \mathrm{C} / 5 \mathrm{~min}$.; 40 cycles of $95^{\circ} \mathrm{C} / 1 \mathrm{~min}$., $45^{\circ} \mathrm{C} / 1$ min., and $72^{\circ} \mathrm{C} / 2 \mathrm{~min}$. A final extension was added at $72^{\circ} \mathrm{C} / 5 \mathrm{~min}$. The reaction products were visualized on agarose gel (1.5\%), using the LowRanger marker (100 bp, Norgen Biotec).

\section{Statistical analysis}

The morphological characteristics (PL, PBW, PMW, EL, BWBE, MWBE, PWBE, AWBE, RL, RAW, RBW, HL, and TBL) of the male and female insects of each population were analyzed, and the data obtained was submitted to variance analysis with the significance of the effects verified by the $\mathrm{F}$ test, at $1 \%$ probability. Principal component analysis (PCA) was performed to determine the relative contribution of the morphological characteristics.

For the molecular data analysis, a matrix of 0 and 1 was constructed, and the estimate of genetic similarity (Sgij) between each pair of populations was calculated by the Nei coefficient (1972). The dominant markers do not allow heterozygous individuals to be distinguished, thus, the frequency of alleles in populations with random mating can be determined by the Hardy-Weinberg balance (Souza et al., 2008), as is the case of populations of $A$ grandis. The estimates included the number of loci, the percentage of polymorphic bands (\% Pol) and the expected heterozygosity (He). The grouping was done by the hierarchical method UPGMA (Cruz and Carneiro, 2003). In addition, molecular variance analysis (AMOVA) was performed. All analyses were performed using the GENES statistical program version 2018.5.3 (Cruz, 2016).

\section{RESULTS AND DISCUSSION}

\section{Morphometric analysis}

After determining the sex of the $A$. grandis insects, it was noted that the percentage of females was higher than the percentage of males in all populations evaluated (Table 2; Figure 2). The insects were collected from flower buds, a plant organ that females use to carry out two processes, feeding and oviposition, thus, there is a tendency to find a greater number of females in relation to males in these plant structures. Longevity might have been another factor that contributed to this result, since females have greater longevity than males (Kumano et al., 2010; Azambuja and Degrande, 2014).

The measured variables of the 10 populations analyzed were significant, for both males and females (Table 3). Females had the highest averages in most of the characteristics. It was also possible to observe that in the 10 populations the female averages were higher than the male averages, except in the municipalities of RondonópolisMT, Goiânia-GO and Campina Grande-PB, where the males had higher averages in some 
characteristics. In general, females of $A$. grandis are larger than males due to biological needs. The size of the body can affect the performance and adaptation of insects (Huang et al., 2018); in some species large females can provide advantages, such as greater fertility and mating capacity (Durocher-Granger et al., 2011). According to Foelker and Hofatetter (2014), females often exhibit different sizes than males, as it improves reproduction and feeding efficiency. Another characteristic of Curculionidae that differentiates females from males is the rostrum; in females this structure is generally larger and flatter than in males (Soto and Reyes, 2014), which should facilitate the feeding process.

Table 2. Geographic coordinates of the Brazilian municipalities where specimens of Anthonomus grandis were collected and the percentage of males (M) and females (F) from each population.

\begin{tabular}{|c|c|c|c|c|c|c|}
\hline Municipality & Lat. & Long. & Alt. & Region & $\mathbf{M}$ & $\mathbf{F}$ \\
\hline Barbalha, CE & $7^{\circ} 17^{\prime} 54.99^{\prime \prime S}$ & $39^{\circ} 18^{\prime} 8.76^{\prime \prime O}$ & 396 & Caatinga & 30 & 70 \\
\hline Quixeramobim, CE & $5^{\circ} 11 ' 31.15^{\prime \prime S}$ & $39^{\circ} 17^{\prime} 36.24^{\prime \prime O}$ & 205 & Caatinga & 28 & 72 \\
\hline Campina Grande, PB & $7^{\circ} 13^{\prime} 46.52^{\prime \prime S}$ & $35^{\circ} 52^{\prime} 54.75^{\prime \prime} \mathrm{O}$ & 517 & Caatinga & 46 & 54 \\
\hline Goiânia, GO & $16^{\circ} 41^{\prime} 15.26^{\prime \prime S}$ & $49^{\circ} 15^{\prime} 53.03^{\prime \prime} \mathrm{O}$ & 782 & Cerrado & 36 & 64 \\
\hline Jataí, GO & $17^{\circ} 533.03 " \mathrm{~S}$ & $51^{\circ} 43^{\prime} 39.80^{\prime \prime} \mathrm{O}$ & 764 & Cerrado & 42 & 58 \\
\hline Chapadão do Céu, GO & $18^{\circ} 23^{\prime} 41.64^{\prime \prime S}$ & $52^{\circ} 39^{\prime} 55.27 " \mathrm{O}$ & 842 & Cerrado & 26 & 74 \\
\hline Chapadão do Sul, MS & $18^{\circ} 47^{\prime} 39.60^{\prime \prime S}$ & $52^{\circ} 37^{\prime} 9.09^{\prime \prime O}$ & 817 & Cerrado & 40 & 60 \\
\hline Ipiranga do Norte, MT & $12^{\circ} 14^{\prime} 27.76^{\prime \prime S}$ & $56^{\circ} 9^{\prime} 8.87^{\prime \prime} \mathrm{O}$ & 387 & Cerrado & 40 & 60 \\
\hline Rondonópolis, MT & $16^{\circ} 27^{\prime} 55.71 " \mathrm{~S}$ & $54^{\circ} 38^{\prime} 19.40^{\prime \prime} \mathrm{O}$ & 268 & Cerrado & 30 & 70 \\
\hline Primavera do Leste, MT & $15^{\circ} 33 ' 37.87^{\prime \prime S}$ & $54^{\circ} 17^{\prime} 42.20^{\prime \prime} \mathrm{O}$ & 656 & Cerrado & 32 & 68 \\
\hline
\end{tabular}

Lat. - latitude; Long. - longitude; Alt. - altitude (m).
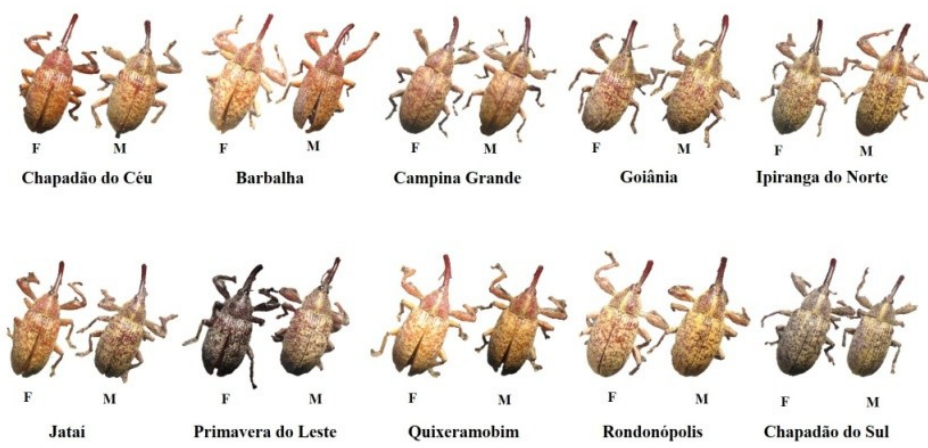

Figure 2. Female (F) and male (M) of Anthonomus grandis from each population from 10 municipalities, distributed in five Brazilian states.

The largest morphometric measurements were found in the boll weevil specimens from the populations in Chapadão do Sul-MS, Chapadão do Céu-GO and Primavera do Leste-MT, and the lowest averages in the weevil specimens from Campina Grande-PB and Quixeramobim-CE. These variations in the size of the boll weevil may be related to the geographic coordinates of the municipalities where the specimens were collected, as insects from locations with higher latitudes tend to be larger than those collected in locations with lower latitudes (Shelomi, 2012; Tseng and Pari, 2019). The insects in the Northeast tend to complete their cycle faster due to the greater number of degree days in the region, compared to the others. Thus, the shorter time between oviposition and the total cycle of the immature 
phase, due to the number of degree days, is a determining factor for the size of insects. In this study, the municipalities with the highest latitudes are Chapadão do Sul-MS and Chapadão do Céu-GO and the municipalities with the lowest latitudes are QuixeramobimCE and Campina Grande-PB (Table 2). This may explain, in part, why the weevils from Chapadão do Sul-MS and Chapadão do Céu-GO presented most of the largest morphometric measurements, when compared to those collected in Quixeramobim-CE and Campina Grande-PB.

Table 3. Means $(\mathrm{mm}) \pm$ standard error and summary of the analysis of variance of the morphometric characteristics of male and female insects of Anthonomus grandis, from 10 Brazilian populations.

\begin{tabular}{|c|c|c|c|c|c|c|c|c|c|c|c|c|c|c|}
\hline Municipality & Sex & PL & PWB & PMW & EL & BWBE & MWBE & PWBE & AWBE & RL & RAW & RBW & HL & TBL \\
\hline \multirow{2}{*}{ Barbalha } & $\mathrm{M}$ & $1.27 \pm 0.042$ & $1.84 \pm 0.020$ & $1.58 \pm 0.047$ & $4.01 \pm 0.052$ & $1.96 \pm 0.031$ & $2.55 \pm 0.053$ & $1.81 \pm 0.098$ & $0.38 \pm 0.015$ & $1.95 \pm 0.050$ & $0.18 \pm 0.010$ & $0.33 \pm 0.008$ & $2.46 \pm 0.074$ & $7.63 \pm 0.084$ \\
\hline & $\mathrm{F}$ & $1.35 \pm 0.019$ & $1.94 \pm 0.020$ & $1.71 \pm 0.025$ & $4.09 \pm 0.061$ & $2.08 \pm 0.029$ & $2.63 \pm 0.051$ & $1.67 \pm 0.077$ & $0.39 \pm 0.027$ & $1.91 \pm 0.061$ & $0.19 \pm 0.012$ & $0.34 \pm 0.008$ & $2.35 \pm 0.062$ & $7.69 \pm 0.118$ \\
\hline \multirow{2}{*}{ Rondonópolis } & M & $1.23 \pm 0.031$ & $1.93 \pm 0.047$ & $1.74 \pm 0.039$ & $4.08 \pm 0.115$ & $2.09 \pm 0.049$ & $2.63 \pm 0.055$ & $1.79 \pm 0.057$ & $0.51 \pm 0.026$ & $1.97 \pm 0.076$ & $0.26 \pm 0.011$ & $0.33 \pm 0.009$ & $2.50 \pm 0.098$ & $7.84 \pm 0.226$ \\
\hline & $\mathrm{F}$ & $1.25 \pm 0.032$ & $1.91 \pm 0.045$ & $1.71 \pm 0.042$ & $3.99 \pm 0.092$ & $2.07 \pm 0.045$ & $2.64 \pm 0.055$ & $1.79 \pm 0.055$ & $0.44 \pm 0.015$ & $1.89 \pm 0.047$ & $0.24 \pm 0.009$ & $0.32 \pm 0.010$ & $2.38 \pm 0.051$ & $7.63 \pm 0.162$ \\
\hline \multirow{2}{*}{ Goiânia } & M & $1.11 \pm 0.029$ & $1.78 \pm 0.052$ & $1.58 \pm 0.041$ & $3.79 \pm 0.103$ & $1.92 \pm 0.060$ & $2.43 \pm 0.065$ & $1.78 \pm 0.060$ & $0.58 \pm 0.019$ & $1.87 \pm 0.050$ & $0.25 \pm 0.007$ & $0.31 \pm 0.009$ & $2.27 \pm 0.053$ & $7.27 \pm 0.170$ \\
\hline & $\mathrm{F}$ & $1.12 \pm 0.043$ & $1.71 \pm 0.056$ & $1.56 \pm 0.050$ & $3.55 \pm 0.114$ & $1.85 \pm 0.062$ & $2.35 \pm 0.069$ & $1.67 \pm 0.058$ & $0.55 \pm 0.014$ & $1.80 \pm 0.066$ & $0.23 \pm 0.008$ & $0.30 \pm 0.011$ & $2.19 \pm 0.073$ & $6.89 \pm 0.204$ \\
\hline \multirow{2}{*}{ Quixeramobim } & M & $1.21 \pm 0.019$ & $1.81 \pm 0.025$ & $1.64 \pm 0.026$ & $3.86 \pm 0.108$ & $1.92 \pm 0.035$ & $2.51 \pm 0.058$ & $1.64 \pm 0.085$ & $0.38 \pm 0.021$ & $1.81 \pm 0.055$ & $0.21 \pm 0.011$ & $0.31 \pm 0.007$ & $2.25 \pm 0.056$ & $7.27 \pm 0.140$ \\
\hline & $\mathrm{F}$ & $1.28 \pm 0.025$ & $1.89 \pm 0.039$ & $1.70 \pm 0.031$ & $3.86 \pm 0.108$ & $2.02 \pm 0.030$ & $2.58 \pm 0.057$ & $1.73 \pm 0.073$ & $0.42 \pm 0.011$ & $1.97 \pm 0.049$ & $0.21 \pm 0.011$ & $0.31 \pm 0.007$ & $2.39 \pm 0.040$ & $7.56 \pm 0.137$ \\
\hline Chapadão do & M & $1.37 \pm 0.022$ & $2.15 \pm 0.021$ & $1.89 \pm 0.012$ & $4.59 \pm 0.078$ & $2.30 \pm 0.025$ & $2.90 \pm 0.029$ & $1.85 \pm 0.037$ & $0.46 \pm 0.010$ & $2.01 \pm 0.032$ & $0.28 \pm 0.012$ & $0.35 \pm 0.005$ & $2.53 \pm 0.029$ & $8.53 \pm 0.094$ \\
\hline Sul & $\mathrm{F}$ & $1.44 \pm 0.023$ & $2.19 \pm 0.028$ & $1.94 \pm 0.029$ & $4.63 \pm 0.055$ & $2.35 \pm 0.033$ & $2.97 \pm 0.031$ & $1.90 \pm 0.052$ & $0.47 \pm 0.010$ & $2.17 \pm 0.060$ & $0.26 \pm 0.010$ & $0.35 \pm 0.008$ & $2.66 \pm 0.056$ & $8.75 \pm 0.107$ \\
\hline Ipiranga do & M & $1.28 \pm 0.022$ & $1.97 \pm 0.027$ & $1.73 \pm 0.029$ & $4.18 \pm 0.047$ & $2.10 \pm 0.038$ & $2.63 \pm 0.056$ & $1.60 \pm 0.058$ & $0.42 \pm 0.016$ & $2.05 \pm 0.027$ & $0.20 \pm 0.011$ & $0.34 \pm 0.009$ & $2.52 \pm 0.039$ & $8.03 \pm 0.085$ \\
\hline Norte & $\mathrm{F}$ & $1.29 \pm 0.037$ & $2.04 \pm 0.040$ & $1.78 \pm 0.038$ & $4.19 \pm 0.111$ & $2.17 \pm 0.045$ & $2.70 \pm 0.063$ & $1.65 \pm 0.061$ & $0.45 \pm 0.016$ & $2.14 \pm 0.049$ & $0.22 \pm 0.011$ & $0.35 \pm 0.009$ & $2.62 \pm 0.094$ & $8.02 \pm 0.143$ \\
\hline \multirow[b]{2}{*}{ Campina Grande } & M & $1.09 \pm 0.038$ & $1.62 \pm 0.048$ & $1.36 \pm 0.050$ & $3.70 \pm 0.111$ & $1.83 \pm 0.057$ & $2.24 \pm 0.058$ & $1.63 \pm 0.062$ & $0.46 \pm 0.022$ & $1.73 \pm 0.064$ & $0.22 \pm 0.011$ & $0.30 \pm 0.017$ & $2.17 \pm 0.074$ & $7.03 \pm 0.207$ \\
\hline & $\mathrm{F}$ & $1.08 \pm 0.037$ & $1.57 \pm 0.063$ & $1.30 \pm 0.044$ & $3.53 \pm 0.127$ & $1.77 \pm 0.065$ & $2.20 \pm 0.073$ & $1.66 \pm 0.071$ & $0.44 \pm 0.020$ & $1.58 \pm 0.065$ & $0.21 \pm 0.009$ & $0.27 \pm 0.009$ & $2.03 \pm 0.079$ & $6.66 \pm 0.220$ \\
\hline \multirow{2}{*}{ Jataí } & M & $1.81 \pm 0.061$ & $1.74 \pm 0.031$ & $1.24 \pm 0.049$ & $4.09 \pm 0.064$ & $2.06 \pm 0.028$ & $2.61 \pm 0.041$ & $1.75 \pm 0.059$ & $0.57 \pm 0.020$ & $2.01 \pm 0.047$ & $0.29 \pm 0.009$ & $0.32 \pm 0.006$ & $2.41 \pm 0.045$ & $7.71 \pm 0.122$ \\
\hline & $\mathrm{F}$ & $1.92 \pm 0.037$ & $1.74 \pm 0.034$ & $1.24 \pm 0.027$ & $4.07 \pm 0.091$ & $2.05 \pm 0.035$ & $2.62 \pm 0.051$ & $1.78 \pm 0.079$ & $0.57 \pm 0.028$ & $2.12 \pm 0.059$ & $0.26 \pm 0.009$ & $0.32 \pm 0.007$ & $2.54 \pm 0.055$ & $7.84 \pm 0.157$ \\
\hline \multirow{2}{*}{ Chapadão do Céu } & M & $1.94 \pm 0.038$ & $1.75 \pm 0.033$ & $1.27 \pm 0.022$ & $4.18 \pm 0.067$ & $2.09 \pm 0.038$ & $2.68 \pm 0.045$ & $1.94 \pm 0.042$ & $0.54 \pm 0.021$ & $2.00 \pm 0.034$ & $0.28 \pm 0.010$ & $0.31 \pm 0.006$ & $2.42 \pm 0.040$ & $7.81 \pm 0.113$ \\
\hline & $\mathrm{F}$ & $1.94 \pm 0.030$ & $1.77 \pm 0.030$ & $1.29 \pm 0.024$ & $4.27 \pm 0.064$ & $2.12 \pm 0.036$ & $2.58 \pm 0.108$ & $1.95 \pm 0.043$ & $0.57 \pm 0.026$ & $2.06 \pm 0.047$ & $0.27 \pm 0.011$ & $0.30 \pm 0.009$ & $2.48 \pm 0.037$ & $7.99 \pm 1.111$ \\
\hline \multirow{2}{*}{ Primavera do Leste } & $\mathrm{M}$ & $1.98 \pm 0.035$ & $1.77 \pm 0.035$ & $1.28 \pm 0.036$ & $4.16 \pm 0.083$ & $2.16 \pm 0.046$ & $2.68 \pm 0.054$ & $2.01 \pm 0.058$ & $0.54 \pm 0.014$ & $1.97 \pm 0.085$ & $0.27 \pm 0.011$ & $0.31 \pm 0.011$ & $2.34 \pm 0.049$ & $7.77 \pm 0.146$ \\
\hline & $\mathrm{F}$ & $2.18 \pm 0.021$ & $1.97 \pm 0.022$ & $1.43 \pm 0.025$ & $4.65 \pm 0.048$ & $2.37 \pm 0.026$ & $3.02 \pm 0.040$ & $2.15 \pm 0.107$ & $0.57 \pm 0.024$ & $2.20 \pm 0.035$ & $0.27 \pm 0.008$ & $0.35 \pm 0.009$ & $2.67 \pm 0.031$ & $8.76 \pm 0.091$ \\
\hline VS & DF & \multicolumn{13}{|c|}{ Mean Square - Males } \\
\hline Municipality & 9 & $1.79^{* * *}$ & $0.32^{* *}$ & $0.78^{* *}$ & $0.95^{* *}$ & $0.29 * *$ & $0.45^{* *}$ & $0.27 * *$ & $0.083^{* *}$ & $0.16^{* *}$ & $0.024^{* *}$ & $0.003^{* *}$ & $0.23 * *$ & $2.77^{* * *}$ \\
\hline Residue & 140 & 0.019 & 0.019 & 0.02 & 0.11 & 0.03 & 0.04 & 0.06 & 0.005 & 0.045 & 0.001 & 0.0012 & 0.052 & 0.32 \\
\hline Average & & 1.43 & 1.83 & 1.53 & 4.06 & 2.04 & 2.59 & 1.8 & 0.48 & 1.94 & 0.25 & 0.32 & 2.39 & 7.68 \\
\hline CV (\%) & & 9.72 & 7.54 & 9.4 & 8.23 & 8.02 & 7.84 & 13.89 & 15.13 & 11.01 & 16.51 & 11.17 & 9.57 & 7.38 \\
\hline VS & DF & \multicolumn{13}{|c|}{ Mean Square - Females } \\
\hline Municipality & 9 & $2.23^{* *}$ & $0.48^{* *}$ & $0.86^{* *}$ & $2.19^{* *}$ & $0.53^{* *}$ & $0.9^{* *}$ & $0.40^{* *}$ & $0.074 * *$ & $0.57 * *$ & $0.013 * *$ & $0.0096^{* *}$ & $0.65^{* * *}$ & $6.86^{* *}$ \\
\hline Residue & 140 & 0.015 & 0.024 & 0.018 & 0.12 & 0.027 & 0.059 & 0.073 & 0.006 & 0.045 & 0.002 & 0.0011 & 0.055 & 0.34 \\
\hline Average & & 1.48 & 1.87 & 1.56 & 4.08 & 2.09 & 2.63 & 1.79 & 0.49 & 1.98 & 0.24 & 0.32 & 2.43 & 7.78 \\
\hline CV $(\%)$ & & 8.18 & 8.28 & 8.6 & 8.63 & 7.91 & 9.3 & 15.08 & 16.05 & 10.65 & 16.46 & 10.46 & 9.67 & 7.48 \\
\hline
\end{tabular}

Furthermore, in the Caatinga biome, where food resources are limited and environmental stress is greater, boll weevils tend to have a smaller body size, due to poor availability of food, which may be beneficial, allowing them to be more resistant against food shortages and high temperatures. According to Couvillon and Dornhaus (2010) scarcity of food can benefit the individual physiology of insects, specifically the body size; when food is not available in abundance, smaller insects remain alive longer. On the other hand, in the Cerrado biome, where food resources are abundant, the food consumption of the boll weevil is higher, resulting in larger insects. Larger specimens, in general, have a higher reproductive potential (Durocher-Granger et al., 2011) and greater capacity for movement (Yang, 2000).

Based on the 13 morphometric variables, the second eigenvector (principal component 2) of males and females explained 85.89 and $91.51 \%$, respectively, of the total 
data variability (Table 4). The variables that gave the greatest weight in the composition of the first and second eigenvectors were TBL and PMW, therefore indicating which are important characteristics in the evaluation of $A$. grandis genetic diversity. According to Cruz and Regazzi (2001), total variations greater than $80 \%$ obtained with the first two or three principal components make it possible to assess the dissimilarity of genotypes or populations through scatter plots, having the first components as a reference axis. The scatter plot using only the values of the first two principal components is shown in Figure 3.

Table 4. Estimates of the eigenvalue variance and percentage of the variance of the principal components (PC) from morphometric characteristics of male and female boll weevil insects.

\begin{tabular}{lllllll}
\hline \multirow{2}{*}{ PC } & Eigenvalue & \multicolumn{3}{c}{ Variance (\%) } & \multicolumn{2}{c}{ Accumulated Variance (\%) } \\
\cline { 2 - 6 } & Male & Female & Male & Female & Male & Female \\
\hline 1 & 7.5156 & 8.6959 & 57.81 & 66.90 & 57.81 & 96.90 \\
2 & 3.6621 & 3.1985 & 28.17 & 24.61 & 85.89 & 94.91 \\
3 & 0.7786 & 0.4430 & 5.99 & 3.41 & 91.97 & 98.04 \\
4 & 0.5300 & 0.4072 & 4.08 & 3.13 & 96.04 & 99.08 \\
5 & 0.3188 & 0.1343 & 2.45 & 1.03 & 98.50 & 99.56 \\
6 & 0.0901 & 0.0621 & 0.69 & 0.48 & 99.19 & 99.82 \\
7 & 0.0701 & 0.0349 & 0.54 & 0.27 & 99.73 & 99.58 \\
8 & 0.0269 & 0.0172 & 0.21 & 0.13 & 99.94 & 100.0 \\
9 & 0.0080 & 0.0055 & 0.06 & 0.04 & 100.0 & \\
\hline
\end{tabular}
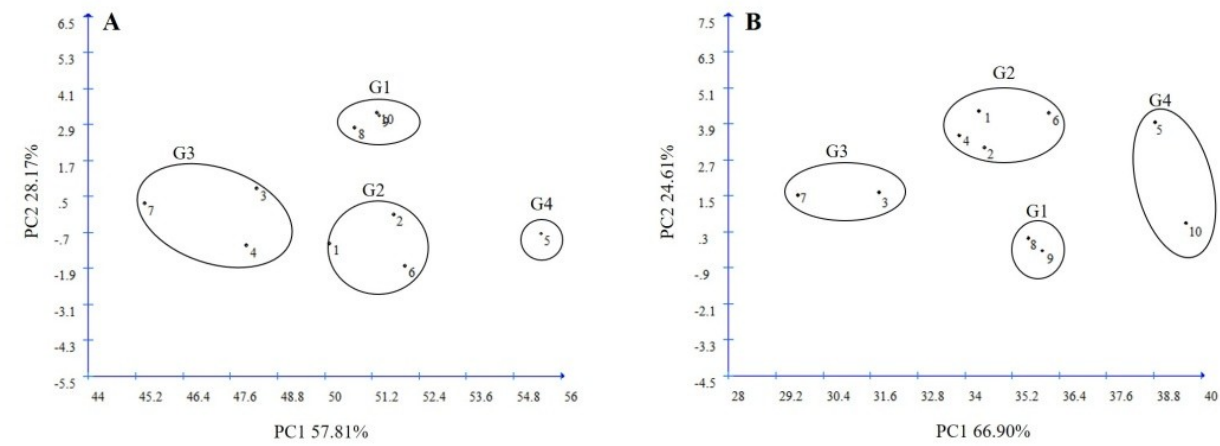

Figure 3. Results of the analysis of the principal components of the morphometric characteristics, showing the position of the 10 populations of boll weevils, males (A) and females (B). 1- Barbalha-CE; 2- Rondonópolis-MT; 3- Goiânia-GO; 4- Quixeramobim-CE; 5- Chapadão do Sul-MS; 6- Ipiranga do Norte-MT; 7- Campina GrandePB; 8- Jataí-GO; 9- Chapadão do Céu-GO; 10- Primavera do Leste-MT. Cerrado region: 2, 3, 5, 6, 8, 9 and 10; Caatinga region: 1,4 and 7.

From the analysis of the main components, the same number of groups formed between males and females was observed, and a similar composition of the groups, that is, groups 1 and 4, of male and female insects consisted of weevil populations only from the Cerrado region, and groups 2 and 3 included the populations from the Caatinga (Figure 3). Variations in the morphometric characteristics of the boll weevil may be related to its ability to adapt and develop in new environments. According to Wan and Yang (2016), the differences in morphometric parameters may be associated with the organism's ability to establish itself in a new geographical range. 


\section{Molecular analysis}

Based on amplifications of ISSR primers on agarose gel (data not shown), the number of loci, percentage of polymorphic bands and expected heterozygosity varied among the studied weevil populations (Table 5). The highest number of loci and the highest percentage of polymorphism occurred in the population of Ipiranga do Norte-MT, while the lowest number of loci and the lowest rate of polymorphism occurred in the populations of Quixeramobim-CE and Primavera do Leste-MT, respectively. By mating at random and assuming the Hardy-Weinberg balance, the expected heterozygosity values ranged from 0.076 to 0.205 .

Table 5. Number of loci, percentage of polymorphic bands (Pol) and expected heterozygosity (He) of ISSR primers used in the characterization of adult populations of cotton boll weeds from 10 municipalities, distributed in five Brazilian states.

\begin{tabular}{llll}
\hline Population & No. Loci & Pol (\%) & He \\
\hline Barbalha-CE & 66 & 52 & 0.107 \\
Quixeramobim-CE & 62 & 63 & 0.124 \\
Campina Grande-PB & 78 & 68 & 0.205 \\
Goiânia-GO & 71 & 43 & 0.092 \\
Jataí-GO & 76 & 69 & 0.178 \\
Chapadão do Céu-GO & 63 & 40 & 0.084 \\
Chapadão do Sul-MS & 74 & 41 & 0.093 \\
Ipiranga do Norte-MT & 84 & 73 & 0.198 \\
Rondonópolis-MT & 68 & 46 & 0.102 \\
Primavera do Leste-MT & 70 & 33 & 0.076 \\
\hline Average & 71 & 53 & 0.126 \\
\hline
\end{tabular}

Kim and Sappington (2004b) used the molecular marker RAPD (random amplification of polymorphic DNA) to infer the magnitude and pattern of genetic differentiation between boll weevil populations in 18 states in the United States and Mexico. The percentage of polymorphism varied between 13.6 and 76.6 and the heterozygosity ranged from 0.071 to 0.293 . Kim and Sappington $(2004 \mathrm{c})$, when evaluating 90 individuals of boll weevils, collected in the south of Texas and northeast of Mexico, using microsatellite molecular markers, obtained a variation of three to 10 alleles per locus and the values of heterozygosity ranged from 0.459 to 0.737 . In the study by Souza et al. (2008) the average polymorphism and heterozygosity rates expected from different populations of the bean weevil, Zabotres subfasciatus (Coleoptera: Bruchidae) when using the ISSR marker, were $83.8 \%$ and 0.288 , respectively, and the genetic variability between populations was considered low. Taking this classification as a reference, our data lead us to infer that there is genetic variability between different populations of boll weevils; however, it is low.

This result probably occurred because the boll weevil is not an insect native to Brazil, introduced recently, about 37 years ago, when compared to its existence of almost two centuries in other countries, such as Mexico and the United States. Martins et al. (2007), stated that low values of heterozygosity are expected in populations of invasive insects that were recently introduced to the area. According to Kim and Sappington (2004a) and Scataglini et al. (2006), it is common to find introduced species with low levels of genetic diversity, since the diversity found in areas that were recently colonized is 
composed of a small portion of the genetic diversity existing in the centers of origin, due to the founding effect.

The partition of genetic variation was performed at two levels: within populations and between populations, through AMOVA. The genetic variation within the population was $42.69 \%$, while between populations it was $57.30 \%$, indicating that the genetic variability between populations was greater than within populations. The values of genetic variation were significant $(\mathrm{P} \leq 0.001)$ for the two sources of variation, with probabilities calculated by 1,000 random permutations, with the value of genetic differentiation of populations (FST) of 0.552 .

The genetic distance values of Nei (1972) were used to construct the dendrogram using the UPGMA hierarchical clustering method (Figure 4). The formation of two population groups was observed after adopting the $95 \%$ cutoff point, according to Mojena's criteria (1977), with $\mathrm{k}=1.25$, which corresponded to the genetic distance of 0.34 . The average estimates of genetic distances between populations obtained from the Nei coefficient (1972) ranged from 0.03 to 0.36 , reflecting the genetic diversity among the 10 populations evaluated. The co-phenetic correlation coefficient was 0.91 , indicating a good representation of the dissimilarity matrices in the form of a dendogram (Cruz and Carneiro, 2003).

Group A aggregated the weevil populations from the municipalities of Rondonópolis, Goiânia, Chapadão do Sul, Chapadão do Céu, Primavera do Leste, Barbalha, Jataí, and Quixeramobim; group B grouped the populations of Ipiranga do Norte and Campina Grande. Group A included six populations belonging to the Midwest region and two populations from the Northeast; these stand out as cotton producing regions, thus having a generally homogeneous environment. Although the boll weevil has high mobility and dispersion power over long distances (Azambuja and Degrande, 2014; Gabriel, 2016), the dispersion through human activities through the movement of plant samples, for the purpose of research and planting, may have favored the efficient colonization of $A$. grandis in areas that it would not easily reach through natural means. The clusters formed through the molecular data were different from the clusters formed through the morphometric data, this indicates that the variability found in the morphometric data had greater influence of the climatic conditions, geographic coordinates of each locality, as well as with the insects feeding.

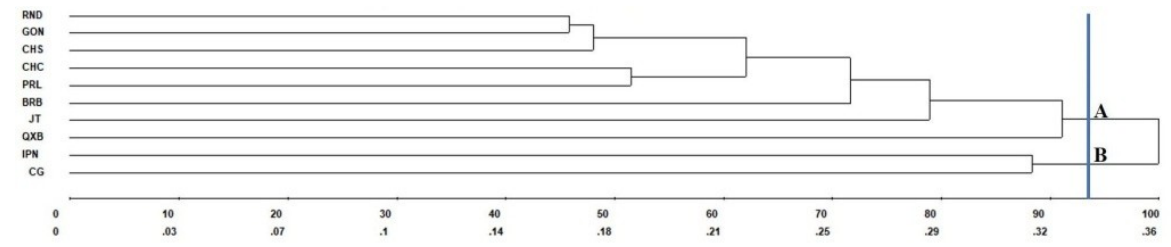

Figure 4. Dendrogram obtained by the UPGMA hierarchical clustering method, based on molecular data (ISSR markers), constructed from the arithmetic complement of the Nei Coefficient. Populations: (BRB) Barbalha, (RND) Rondonópolis, (GON) Goiânia, (CHS) Chapadão do Sul, (QXB) Quixeramobim, (IPN) Ipiranga do Norte, (CG) Campina Grande, (JT) Jataí, (CHC) Chapadão do Céu, (PRL) Primavera do Leste. The letters indicate the two groups formed among the 10 populations analyzed.

The results obtained in our study indicate that the genetic structure of the studied weevil populations is weak and that geographically close populations are not necessarily the most similar from a genetic point of view. In addition, the low intrapopulation diversity may 
be an indication of the existence of an extensive contemporary gene flow among genetically distant populations.

This low genetic diversity and weak geographical structure of the boll weevil in Brazil can be attributed to several factors. The boll weevil is an exotic pest that was recently introduced in Brazil (Azambuja and Degrande, 2014). Newly introduced pest insect species, in general, have low genetic diversity because they are composed of a small portion of individuals from the population of origin due to the founding effect (Kim and Sappington, 2004a). The weevil reproduces sexually, has a short life cycle (approximately 20 days), produces an average of five generations per crop, has high local mobility and can disperse over long distances (Azambuja and Degrande, 2014; Gabriel, 2016). This prevents the geographic isolation of its populations (Manrique-Poyato et al., 2013), making it difficult for the emergence of genetically differentiated populations. In the work carried out by Souza et al. (2008), populations of $Z$. subfasciatus showed weak genetic structure, and one of the factors that may have contributed to this result, as with the A. grandis, is the fact that this species is not native to the country. According to Scataglini et al. (2006) the phylogeographic approach is appropriate for evolutionary studies of boll weevils, including the evaluation of geographic structure and the analysis of genetic variation within and between populations.

\section{ACKNOWLEDGMENTS}

Embrapa for financial support; the Coordination for the Improvement of Higher Education Personnel (CAPES) for the scholarship granted; Dr. Roseane Cavalcante dos Santos and Dr. Jean Pierre Cordeiro Ramos (Embrapa Algodão) for the suggestions in the statistical analyzes; and Daniel da Silva Gomes for the elaboration of Figure 1.

\section{CONFLICTS OF INTEREST}

The authors declare no conflict of interest.

\section{REFERENCES}

Almeida RP, Silva CAD and Ramalho FS (2008). Manejo integrado de pragas do algodão. In: O agronegócio do algodão no Brasil (Beltrão NEM, Azevedo DMP, eds.). Embrapa Informação Tecnológica, Campina Grande, 1034-1098.

Azambuja R and Degrande PE (2014). Thirty years of cotton boll weevil in Brazil. Arquivos do Instituto Biológico. 81: $377-410$.

Bancroft HR and Jones BR (1977). Genotypes of esterase II determined from frass of Anthonomus grandis Boh. (Coleoptera, Curculionidae). Biochem. Genet. 15: 1175-1180.

Belot JL (2015). O bicudo-do-algodoeiro (Anthonomus grandis BOH., 1843) nos cerrados brasileiros: biologia e medidas de controle. 2nd edn. IMA-MT, Cuiabá.

Couvillon MJ and Dornhaus A (2010). Small worker bumble bees (Bombus impatiens) are hardier against starvation than their larger sisters. Insectes Soc. 57: 193-197.

Cruz CD and Regazzi AJ (2001). Modelos biométricos aplicados ao melhoramento genético. 2nd edn. Editora UFV, Viçosa.

Cruz CD and Carneiro PCS (2003). Modelos biométricos aplicados ao melhoramento genético. 3rd edn. Editora UFV, Viçosa.

Cruz CD (2016). Genes Software - extended and integrated with the R, Matlab and Selegen. Acta Sci. 38: 547-552.

Doyle JJ and Doyle JL (1987). A rapid DNA isolation procedure for small quantities of fresh leaf tissue. Phytochemical Bulletin 19: 11-15.

Durocher-Granger L, Martel V and Boivin G (2011). Gamete number and size correlate with adult size in the egg parasitoid Trichogramma euproctidis. Entomol. Exp. Appl. 140: 262-268. 
Ferreira ME and Grattapaglia D (1998). Introdução ao uso de marcadores moleculares em análise genética. 2nd edn. Embrapa Cenargen, Brasília.

Foelker CJ and Hofstetter RW (2014). Heritability, Fecundity, and sexual size dimorphism in four species of bark beetles (Coleoptera: Curculionidae: Scolytinae). Ann. Entomol. Soc. Am. 107: 143-151.

Fornel R and Cordeiro-Estrela P (2012). Morfometria geométrica e a quantificação da forma dos organismos. In: Temas Em Biologia: Edição Comemorativa aos 20 anos do Curso de Ciências Biológicas e aos 5 anos do PPG-Ecologia a URI Campus de Erechim (Marinho JR, Hepp LU, Fornel R, eds.). EDIFAPES, Erechim, 101-120.

Gabriel D (2016). O bicudo do algodoeiro. Documento Técnico-Agência Paulista de Tecnologia dos Agronegócios/Instituto Biológico. 25: 1-20.

Hernández MS, Jones RW and Castillo PR (2013). A key to the Mexican and Central America Genera of Anthonomini (Curculionidae, Curculioninae). ZooKeys. 260: 31-47.

Huang Y, Ao Y, Jiang M and Way MO (2018). Variation of body size in rice water weevil (Coleoptera: Curculionidae) and its associations with population biology. J. Insect Sci. 18: 1-4.

IBGE-Instituto Brasileiro de Geografia e Estatística. Produção Agrícola - Lavoura Temporária 2019. Available at: [https://cidades.ibge.gov.br/brasil/mt/primavera-do-leste/pesquisa/14/10193?tipo=ranking]. Accessed March 19, 2021.

Jarne P and Lagoda PJL (1996). Microsatellites, from molecules to populations and back. Trends in ecology \& Evolution. 11: 424-429.

Jimenez LH, Ranz RR, López RC, Elgueta M, et al. (2018). Morphometric and molecular differences among Calvertius tuberosus (Coleoptera: Curculionidae) populations associated with Andean and coastal populations of Araucaria araucana in the La Araucanía Region, Chile. Rev. Bras. Entomol. 62: 119-124.

Kalia RK, Rai MK, Kalia S, Singh R, et al. (2011). Microssatelite markers: an overview of the recent progress in plants. Euphytica. 177: 309-304.

Kim KS and Sappington TW (2004a). Boll weevil (Anthonomus grandis Boheman) (Coleoptera: Curculionidae) dispersal in the Southern United States: evidence from mitochondrial DNA variation. Environ. Entomol. 33: 457470.

Kim KS and Sappington TW (2004b). Genetic structuring of boll weevil populations in the US based on RAPD markers. Insect Mol Biol. 13: 293-303.

Kim KS and Sappington TW (2004c). Isolation and characterization of polymorphic microsatellite loci in the boll weevil, Anthonomus grandis Boheman (Coleoptera: Curculionidae). Molecular Ecology Notes. 4: 701-703.

Kim KS, Szendrei Z, Rodriguez-Saona C, Mulder Junior PG, et al. (2009). Molecular diagnostic for boll weevil (Coleoptera: Curculionidae) based on amplification of three species-specific microsatellites. J. Econ. Entomol. 102: 759-766.

Kumano N, Iwata N, Kuriwada T, Shiromoto K, et al. (2010). The neogregarine protozoan Farinocystis sp. reduces longevity and fecundity in the West Indian sweet potato weevil, Euscepes postfasciatus (Fairmaire). J. Invertebr. Pathol. 105: 298-304.

Manrique-Poyato MI, López-León MD, Gómez R, Perfectti F, et al. (2013) Population genetic structure of the grasshopper Eyprepocnemis plorans in the south and east of the Iberian Peninsula. PLoS One 8: 1-8.

Martinelli S and Omoto C (2006). Resistência de lepidoteros-praga a inseticidas na cultura do algodão no Brasil. Rev. Bras. Ol. Fibros. 10: 1167-1182.

Martins WFS, Ayres CFJ and Lucena WA (2007). Genetic diversity of Brazilian natural populations of Anthonomus grandis Boheman (Coleoptera: Curculionidae), the major cotton pest in the New World. Genet. Mol. Res. 6: 23-32.

Miranda JE and Rodrigues SMM (2018). O tamanho do prejuízo do bicudo e a necessidade do monitoramento. Cultivar Grandes Culturas. 19: 8-11.

Mojena R (1977). Hierarquical grouping method and stopping rules: an evaluation. Comput. J. 20: 359-363.

Nei M (1972). Genetic distances between populations. Am. Nat. 106: 283-292.

Ng WL and Tan SG (2015). Inter-simple sequence repeat (ISSR) markers: are we doing it right. ASM Sci. J. 9: 30-39.

Ober K and Connolly CT (2015). Geometric morphometric and phylogenetic analyses of Arizona Sky Island populations of Scaphinotus petersi Roeschke (Coleoptera: Carabidae). Zoo. J. Linn. Soc. 175: 107-118.

Parra JRP (2014). Biological Control in Brazil: an overview. Sci. Agric. 71: 420-429.

Reis SF (1988). Morfometria e estatística multivariada em biologia evolutiva. Rev. Bras. Zool. 5: 571-580.

Ribeiro PA, Sujii ER, Diniz IR, Medeiros MA, et al. (2010). Alternative food sources and overwintering feeding behavior of the boll weevil, Anthonomus grandis Boheman (Coleoptera: Curculionidae) under the tropical conditions of Central Brazil. Neotrop. Entomol. 39: 28-34.

Sappington TW and Spurgeon DW (2000). Preferred technique for adult sex determination of the boll weevil (Coleoptera: Curculionidae). Ann. Entomol. Soc. Am. 93: 610-615.

Scataglini MA, Lanteri AA and Confalonieri VA (2006). Diversity of boll weevil populations in South America: a phylogeographic approach. Genetica. 126: 353-68.

Shelomi M (2012). Where are we now? bergmann's rule sensu lato in insects. Am. Nat. 180: 511-519.

Silva CAD and Ramalho FS (2013). Kaolin spraying protects cotton plants against damages by boll weevil Anthonomus grandis Boheman (Coleoptera: Curculionidae). J. Pest. Sci. 86: 563-569.

Genetics and Molecular Research 20 (2): gmr18771

CFUNPEC-RP www.funpecrp.com.br 
Smith-Pardo AH (2015). Species of the beetle genus Anthonomus Germar, 1817 (Curculionudae: Curculioninae: Anhthonomini) of quarantine importance intercepted at U.S. ports of entry. Boletin del Museo Entomológico. 7: 718.

Soto M and Reyes P (2014). New distributional records of two species of Anthonomocyllus (Curculionidae, Anthonomini) for Mexico. Rev. Colomb. Entomol. 40: 292-295.

Souza GAD, Carvalho MRDO, Martins ER, Guedes RNC, et al. (2008). Diversidade genética estimada com marcadores ISSR em populações brasileiras de Zabrotes subfasciatus. Pesq. Agropec. Bras. 43: 843-849.

Terranova AC, Jones RG and Bartlett AC (1991). An allozyme study of the laboratory boll weevil and its influence on some southeastern populations. Southwest. Entomol. 16: 1-11.

Tseng M and Pari S (2019). Body size explains interspecific variation in size-latitude relationships in geographically widespread beetle species. Ecol. Entomol. 44: 151-156.

Wan FH and Yang NW (2016). Invasion and management of agricultural alien insects in China. Annu. Rev. Entomol. 61: $77-98$.

Yang LH (2000). Effects of body size and plant structure on the movement ability of a predaceous stinkbug, Podisus maculiventris (Heteroptera: Pentatomidae). Oecologia. 125: 85-90. 